\title{
Family Firm Identity Approach: A Systematic Literature Review
}

\author{
Beskida S. Dorda ${ }^{1} \&$ Eriona M. Shtëmbari ${ }^{2}$ \\ ${ }^{1}$ University of New York Tirana, Tirana, Albania \\ ${ }^{2}$ Business and Economics Department, University of New York Tirana, Tirana, Albania \\ Correspondence: Beskida S. Dorda, University of New York Tirana, Tirana, Albania. E-mail: \\ beskida_dorda@yahoo.com
}

Received: October 11, 2019

Accepted: November 30, 2019

Online Published: December 29, 2019

doi:10.5539/ijbm.v15n1p166

URL: https://doi.org/10.5539/ijbm.v15n1p166

\begin{abstract}
Family business is created when the family leads commercial activities. This intersection represents emotions and trade within the same entity, driving attention toward intangible resources. History has shown that families can gather together and run successful businesses.

Non-financial topics are capturing the attention of the management field, and family firm identity (FFI) is an interesting topic for those who want to study more in-depth this type of business. This paper will give a review of the academic literature about the FFI identified as a field that needs to be explored more in depth. Interested researchers will find a general view of how this approach is developed from scholars around the world.

The aim is to present how the family and business identity relate to one another, seen from different perspectives by scholars. Researchers' invaluable contributions are used to design this review, using databases such as Emerald, ProQuest (ABI/INFORM), EBSCOhost and Science Direct. Keywords used for search are family business identity and family firm identity. The data are gathered during May and June 2019. The review shows that several dimensions can influence on the level of FFI. Some of the dimensions which resulted from this study are generations, boundaries, identity conflict, growth, communication and globalization.
\end{abstract}

Keywords: family business identity, family firm identity, review

\section{Introduction}

Each economic entity has its goals. While groups of people dedicate time and energy to those goals, a climate within the company is created and reflected to its stakeholders. In other words, people can collaborate and build their status as a group when they are lead from the same mission aiming to reach the same objectives.

Individuals within the family tend to share the same values and beliefs. It suggests that family members who are at the same time co-workers will continue to communicate using their family approach. Consequently, family and business identity might overlap (Zellweger, Nason, Nordqvist, \& Brush, 2013) giving the perception that family and firm share the same values and each one of them can represent the other. Under these circumstances, harmony is a factor that contributes positively to a healthy business.

Nowadays, the tendency of research on FFs (family firms) is to study nonfinancial aspects of intangible resources. In this perspective, the focus of this paper is on family firm identity (FFI). Family and firms can be identical or not, in terms of what do they value the most and what do they represent. If there is a high level of identification between family and business, we can say that family and firm share almost the same values. In this sense, when companies can be identified as family businesses, a FFI is created.

This paper aims to investigate the identity exchange between family and business. Many scholars joined the stream of research, giving their invaluable contribution to this area. Since it is not a fully explored research area (Astrachan \& Botero, 2017), a literature review can help scholars identify new gaps in the body of knowledge. FFI is one of the essential foundations that can help scholars and practitioners elaborate appropriately on family business intangible resources. Due to certain specific circumstances in which FFs are managed, it resulted that FFI is different from the identity of other companies. In this regard, FFs and their stakeholders can have different perceptions about the FFI.

The contribution of this review stands on giving a general view on how academic literature treated FFI, focusing on the exchanges that happen between two identities. Moreover, this paper will present dimensions, contexts, 
and their results as well.

\section{Methodology}

"Systematic review can be argued to be at the heart of a 'pragmatic' management research, which aims to serve both academic and practitioner communities," wrote Tranfield, Denyer and Smart (2003). While Mulrow (1994) considered it "an invaluable scientific activity", Mays, Pope, and Popay (2005) emphasized the need that policy-makers and managers have for synthesized information for decision-making.

A systematic literature review is used to comprehend academic literature on a particular issue with the purpose to help scholars deal with a large amount of data. It is a contribution that gives to the existed knowledge by synthesizing large quantities of information. Thus, a systematic literature review can guide scholars and practitioners in new directions. This kind of literature review can reduce bias, such as careless and systematic errors (Mulrow, 1994), aiming to make generalizations.

EBSCOhost, ProQuest (ABI/INFORM), Emerald and Science Direct are some of the databases used from this paper. The keywords used to search the information are family business identity and family firm identity. The best-quality analysis can be produced using strict criteria (Tranfield, Denyer \& Smart, 2003). Therefore, this article used only two group of words with the same meaning.

Articles are collected during May -June 2019 and a review protocol is maintained for each database. After the collection, studies are selected based on their content. The content is concentrated in the process of calibration that happens between two identities. If studies examined the concept of FFI as an exchange process between family and firm identities, then they are excepted and analyzed further. The information of each article is synthesized according to predetermined issues, presented in a general table. The main features analyzed for each study are dimensions, context and results.

\section{Discussion/Theoretical Framework}

The term "family business" is used from companies all around the world, not to give information about the ownership but as a label that gives the possibility to differentiate the firm in the market (Blombäck, 2011), adding another dimension or characteristic to the business. In general, family represents tradition, harmony, commitment and mostly the connotation is related to positive outcomes. Although family is seen as a positive element, still certain circumstances hold back FFI from being shared. Some of the factors identified in the literature are: personification, visibility and relevance (Astrachan \& Botero, 2018). If family members are not ready to represent the company and to share their family names, then FFI can not be promoted to outsiders. In general, it is not easy for people to be identified with the business and for this reason FFI represents an interesting topic. When people tend to promote their personal life and company as related to one another, then many important management issues emerge. In this perspective, some families might agree to share their personality with the firm while others might not.

During the review is noted that along with FFI, researchers use "family business brand" which suggests a strong family identity and high involvement of family members in the firm (Astrachan \& Botero, 2018). It means that firms are aware of the significant intersection between two systems called family and business. Due to this awareness, a different approach can be implemented by firms toward their stakeholders. In other words, FFI after being realized is even used through different means, aiming to present a unique characteristic. This unique identity, shaped by family (Sundaramurthy \& Kreiner, 2008; Babina, Astrachan, Botero, Haird, Prügl, Herrmannf, Larocheg \& Sarstedt, 2017), is considered a critical approach to be investigated by research.

Since the overlap between family and business identities can differ in degree (Wielsma \& Brunninge, 2019; Sundamurthy \& Kreiner, 2008), the contribution of this paper consists on exploring the dimensions that scholars used to investigate FFI.

\subsection{The Definition of FFI}

Kansikas and Nemilentsev (2010) stated that the focus of management and leadership research is on understanding conceptually and empirically organizational identity. In this point of view, it is essential to present what FFI represent according to scholars.

FFI is introduced by Zellweger, Eddleston and Kellermanns (2010). They stated that "identity dimension reflects how the family defines the firm and how the firm operates as a whole". Two elements that the FFI reveals are considerations of family members and management. If family members consider the influence of the family in the firm and if this influence affects somehow the administration of the company, then we can say that FFI is present. 
Astrachan, Botero, Astrachan and Prügl (2018) stated that "Family Firm Identity consists of the identity of the owning family and the business, which are integrated to a certain degree - the more aligned the family and business values and goals, the larger the overlap.”. According to Astrachan, Botero, Astrachan and Prügl (2018), who studied several definitions from different authors, FFI represents the leader's perception of the company. In this point of view, the company's profile is generally shaped by leaders. FFI is one of the features that might be encouraged or influenced through dedication and daily routines.

"Are we a family firm?" is the question proposed by several authors (Wielsma \& Brunninge, 2019; Astrachan \& Botero, 2018) aiming to understand if firms do consider or not themselves as family firms. This issue is an internal perception of the company considered necessary for experiencing FFI. According to Brunninge and Melander (2010), FFI can be general or specific. When the business identifies itself as a family firm is considered general. The term specific implies the identification with the fact of being a family firm while adding other values that represent family heritage.

\subsection{Studies' Analysis}

The concept of familiness came from Resource-Based view and from familiness came the concept of FFI, being considered as the third dimension of familiness along with involvement and essence (Zellweger, Eddleston, \& Kellermanns, 2010). Familiness was considered as a possibility to provide competitive advantage from intangible resources. The possibility to be identified as businesses with familiness, brought research toward FFI (Astrachan \& Botero, 2018).

Research has proven that individuals relate the term of 'family firm' with tradition and continuity, small and medium companies, trustworthiness, strong culture, corporate citizenship, professionalism, and career opportunities (Botero, Astrachan \& Calabrò, 2018). The positive attributions that people give to FFs (Family Firms) can be influenced by a sustainable and robust identity that left traces in their community.

Other studies investigate on how FFI is presented through websites (Botero, Thomas, Graves \& Fediuk, 2013) and more than half of the companies taken into consideration (1036 companies) did specify that they are FFs. The decision to communicate the family business brand to outsiders or stakeholders was found related to FFI (Astrachan \& Botero, 2018). Different levels of FFI resulted in affecting the way FFs represent themselves. Some FFs are proud to be identified as FFs, while others do not emphasize at all the family involvement in the business. The term "family business", studied as a part of corporate brand identity, is used in the websites as a way to identify them (Blombäck \& Ramírez-Pasillas, 2010). Results show that corporate brand identity is driven by individual identity, habit and marketing strategy, reasons why companies orient their behavior toward FFI or not.

Identity is seen under the boundary theory and factors like image, culture, personnel, ownership/governance and contractual relations with family are explored. Moreover, the financial relationship between family and business resulted important in shaping FFI (Sundaramurthy \& Kreiner, 2008). Furthermore, FFI can intentionally be manipulated if firms want to change the level of combination between two identities. Two sets of factors pointed out from Sundaramurthy \& Kreiner (2008) that affect on FFI are individual factors and situational context. Individual factors include founder's belief, age and gender. Situational context includes national cultures, rural/urban cultures, family culture and organizational life-cycle. Each one of those factors has its influence on FFI, suggesting that different combinations can create unique identities.

The literature emphasize that FF reflects the identity of its founder. Studies show that during the first stages of the business, founders start to create the identity of FFs. While moving towards the other phases, there are also new family members who join the firm and new circumstances that influence on the company's individuality (Parada \& Dawson, 2017).

Table 1. FFI and business life-cycle

\begin{tabular}{|c|c|c|c|c|c|c|}
\hline \multirow[b]{3}{*}{$\begin{array}{l}\text { Relationship } \\
\text { identities }\end{array}$} & \multicolumn{6}{|c|}{ Business' stages } \\
\hline & & Early stage & Middle stage & & & Late stage \\
\hline & between & $\begin{array}{l}\text { Founder's and family's identity } \\
=>\text { Business identity }\end{array}$ & $\begin{array}{l}\text { Family identity } \\
\text { identity }\end{array}$ & $<=$ & Business & $\begin{array}{l}\text { Family identity } \neq \text { Business } \\
\text { identity }\end{array}$ \\
\hline
\end{tabular}

Source: Parada \& Dawson, 2017; Wielsma \& Brunninge, 2019.

The table above shows how FFI and family identity relate to one another in different stages of the firm. It reveals 
that FFI can change over time. As we said earlier, family identity is transmitted from the founder to the business during the early stage, but the opposite situation happens in the middle stage. While the two first phases exchange their identities, in the late one, there is a possible differentiation, due to the consolidation of the business. During the late phase, professional management takes place and run the majority of the company's activity. In this phase, it seems like family and business are not affected by one another any more.

Stories told by family members (Parada \& Dawson, 2017) are considered important factors that help create a unique personality. They help in building a special bond between members. FFI was proved to be transformed even by globalization through merges, acquisitions, competition and succession (Kansikas \& Nemilentsev, 2010). Interestingly enough, research shows that the level of FFI is different even through generations. During the first and fourth generation resulted that the identity to the family business is high. Moreover, during the second generation, the FFI had low values (Nunnemacher, 2016). Trust and identity represent critical factors that contribute to the succession of the business. Results show that firms create a good reputation when family's name is used to represent their activity (Deephouse \& Jaskiewicz, 2013). Family members are those who resulted in having a strong identity toward their business compared to non-family members working in a family business or non-family business (Deephouse \& Jaskiewicz, 2013). It represents the strong relationship within the family transmitted to the company.

Depending on the degree of how the identity of family and business are integrated and how these identities choose their priorities, scholars have called them hybrid identity companies (Whetten, Foreman \& Dyer, 2014). It is important to emphasize here that FFI level or type is affected by the way family and firm include their members and also give precedence to identities. If the participation of family members is meaningful and each one of them plays an important role in the business, a strong FFI can be build. As a result, exchanges between values can easily shape the identity of the company.

Why companies that involve family members, share or not the fact that they belong to the same family? The results of a study gave two motives: identity-related, which represents the level of internal family-business overlap and expectation-driven, which represents the external benefits of the firm (Astrachan \& Botero, 2018). Factors identified for both motives are identification and commitment of the family members, pride, differentiation in the market, stakeholder benevolence and superior image. For example: being proud of what prior generations have done for the business is a factor that can make companies willing to share their achievements and heritage (Astrachan \& Botero, 2018). As a result, the FFI can experience high levels.

The positive relationship between business family identity and FF growth resulted in helping overcome conflicts between family owners (Calabrò, Campopiano \& Basco, 2017). Conflict within FFs is considered as a negative factor that can harm their performance, and some of the reasons can be found at FFI. For example, firms that share a high level of FFI might solve their disagreements more smoothly compared to other companies with a low level of FFI. The reason has to do with connection and cooperation between family members expressed by FFI.

The dual identity of FF is studied using qualitative methods to understand how family's identity is treated from management (Masri, Tekathen, Magnan \& Boulianne, 2017). Findings show that management control technologies can change the firms' identity, orienting them towards a stronger business identity and a weaker family identity. Under these circumstances, professional management can influence the way people perceive the family and its business.

A high FFI proves to produce higher economic performance and at the same time to orient the FF towards key nonfamily stakeholders (de la Cruz Déniz-Déniz, Cabrera-Suárez, Martín-Santana, 2018). FFI is also studied in the financial approach, using financial decisions. High and long-term debts resulted in being the characteristic of the FFs compared to nonfamily firms (Thiele \& Wendt, 2017). Moreover, organizational identification (OI) in family firms is studied related to the wage (Pagliarussi \& Costa, 2017). Results show that firms can benefit from organizational identification because for high levels of OI, the efforts exerted are high, and the wage excepted is low. Interestingly enough, family agents who identify themselves with the company tend to accept lower wages compared to nonfamily managers who have a low level of identification with the company.

Attention is also drawn towards nonfamily members (Memili \& Welsh,2012) and stakeholders (de la Cruz Déniz-Déniz, Cabrera-Suárez \& Martín-Santana, 2018) and how do they relate to the FFI. In most of the cases, family firms have more nonfamily members than family members. Results show that the level of FFI affects the way businesses manage their activity towards key-nonfamily stakeholders, and as a result, the economic performance is affected. The level of attachment and identification with the organization of nonfamily members is related to many dimensions. It means that it is the power, experience and culture of the family firm that can 
help or not nonfamily members to identify themselves with the firm.

Table 2. Dimensions in which FFI is explored by studies

\begin{tabular}{|c|c|c|c|c|}
\hline \multirow[b]{2}{*}{ Year } & \multirow[b]{2}{*}{ Dimensions } & \multirow[b]{2}{*}{ Context } & \multicolumn{2}{|l|}{ Summary } \\
\hline & & & Results & Source \\
\hline 2008 & Boundaries & Segmentation & Individual factors: founder's belief, age, gender. & Sundaramurthy \\
\hline & & Integration & $\begin{array}{l}\text { Situational context: national cultures, rural/urban } \\
\text { cultures, family culture, organisational life-cycle. }\end{array}$ & Kreiner \\
\hline 2008 & $\begin{array}{l}\text { Family-Based } \\
\text { brand identity }\end{array}$ & $\begin{array}{l}\text { Competitive } \\
\text { orientation (Customer } \\
\text { versus product) }\end{array}$ & $\begin{array}{l}\text { Positive relationship between promoting a } \\
\text { family-brand image and performance }\end{array}$ & Craig, Dibrell \& Davis \\
\hline 2009 & Identity conflict & Opportunities & $\begin{array}{l}\text { Opportunities: create or not conflicts between family } \\
\text { and business identities. }\end{array}$ & Shepherd \& Haynie \\
\hline 2010 & Familiness & $\begin{array}{l}\text { Organizational } \\
\text { identity theory }\end{array}$ & $\begin{array}{l}\text { Combinations between involvement, essence and } \\
\text { identity explain the heterogeneity of family firms and } \\
\text { also the fact that some families add distinguished } \\
\text { values to their business compared to others. }\end{array}$ & $\begin{array}{l}\text { Zellweger, Eddleston \& } \\
\text { Kellermanns }\end{array}$ \\
\hline 2010 & Values & $\begin{array}{l}\text { Corporate identity and } \\
\text { globalization }\end{array}$ & $\begin{array}{l}\text { Values of family business corporate identity are: } \\
\text { stakeholder thinking, active behavior/actions and long } \\
\text { term orientation }\end{array}$ & $\begin{array}{l}\text { Kansikas } \\
\text { Nemilentsevișpipi }\end{array}$ \\
\hline 2010 & Globalization & $\begin{array}{l}\text { Merges, acquisitions, } \\
\text { competition and } \\
\text { succession }\end{array}$ & FFI is affected by globalization & Kansikas \& Nemilentsev \\
\hline 2010 & Multi-generation & Familiness & FFI : general and specific & Brunninge \& Melander \\
\hline 2010 & $\begin{array}{l}\text { Identity as a } \\
\text { corporate brand }\end{array}$ & As a process & $\begin{array}{l}\text { Corporate brand identity is driven by three logics: } \\
\text { habit, organic and intended logics }\end{array}$ & $\begin{array}{l}\text { Blombäck, } \\
\text { Ramírez-Pasillas }\end{array}$ \\
\hline 2011 & Value & Consumer behavior & Family business communication affects performance & Blombäck \\
\hline 2013 & Communication & $\begin{array}{l}\text { Websites \& personal } \\
\text { conversations }\end{array}$ & High FFI $=>$ Company communicates its FFI & $\begin{array}{l}\text { Botero, Thomas, Graves } \\
\& \text { Fediuk }\end{array}$ \\
\hline 2013 & Non-financial goals & Identity & $\begin{array}{l}\text { FFI can explain why some firms strive for nonfinancial } \\
\text { goals }\end{array}$ & $\begin{array}{l}\text { Zellweger, Nason, } \\
\text { Nordqvist, \& Brush }\end{array}$ \\
\hline 2013 & Reputation & $\begin{array}{l}\text { Family and nonfamily } \\
\text { firms }\end{array}$ & $\begin{array}{l}\text { A high level of FFI motivates family members for } \\
\text { having a favorable reputation of their firm }\end{array}$ & Deephouse, Jaskiewicz \\
\hline 2014 & Hybrid Identity & Degree of identity & $\begin{array}{l}\text { Combinations between the degree of identity } \\
\text { integration and priority produced four different types of } \\
\text { hybrid family firms. }\end{array}$ & $\begin{array}{l}\text { Whetten, Foreman \& } \\
\text { Dyer }\end{array}$ \\
\hline 2016 & Generations & $\begin{array}{l}\text { Trust, identity and } \\
\text { succession }\end{array}$ & $\begin{array}{l}\text { High FFI in the first and fourth generation and low FFI } \\
\text { in the second generation }\end{array}$ & Nunnemacher \\
\hline 2016 & Generations & $\begin{array}{l}\text { Performance \& } \\
\text { Family governance }\end{array}$ & $\begin{array}{l}\text { Transgenerational orientation is positively related with } \\
\text { business family identity }\end{array}$ & Suess-Reyes \\
\hline 2017 & $\begin{array}{l}\text { Transgenerational } \\
\text { narrative }\end{array}$ & Business life cycle & $\begin{array}{l}\text { FFI changes according to business life cycle and } \\
\text { founder's influence }\end{array}$ & Parada \& Dawson \\
\hline 2017 & Growth & $\begin{array}{l}\text { Size of the family } \\
\text { owner group }\end{array}$ & $\begin{array}{l}\text { High family identity ( } 8 \text { owner groups) \& Low family } \\
\text { identity }(<8<)\end{array}$ & $\begin{array}{l}\text { Calabrò, Campopiano \& } \\
\text { Basco }\end{array}$ \\
\hline 2017 & $\begin{array}{l}\text { Management } \\
\text { technology }\end{array}$ & $\begin{array}{l}\text { Identity calibration } \\
\text { between family and } \\
\text { firm }\end{array}$ & A higher management technology reduces the FFI & $\begin{array}{l}\text { El Masri, Tekathen, } \\
\text { Magnan \& Boulianne }\end{array}$ \\
\hline 2017 & Term & Consumer perception & $\begin{array}{l}\text { Family firm means: small business, trustworthy, } \\
\text { tradition and continuity and family-based }\end{array}$ & Fotea, Al. Pop \& Fotea \\
\hline 2017 & $\begin{array}{l}\text { Incentives } \\
\text { Contracts }\end{array}$ & Levels of FFI & High FFI $=>$ Low wages and high efforts & Pagliarussi \& Costa \\
\hline 2017 & Financial issues & Decisions & High and long-term debts & Thiele \& Wendt \\
\hline 2017 & Management & Levels of FFI & $\begin{array}{l}\text { Management control technologies }=>\text { stronger business } \\
\text { identity \& weaker family identity }\end{array}$ & $\begin{array}{l}\text { Masri, Tekathen, Magnan } \\
\& \text { Boulianne }\end{array}$ \\
\hline 2018 & Communication & Motives & Motives of promoting family business are related to & Astrachan \& Botero \\
\hline
\end{tabular}




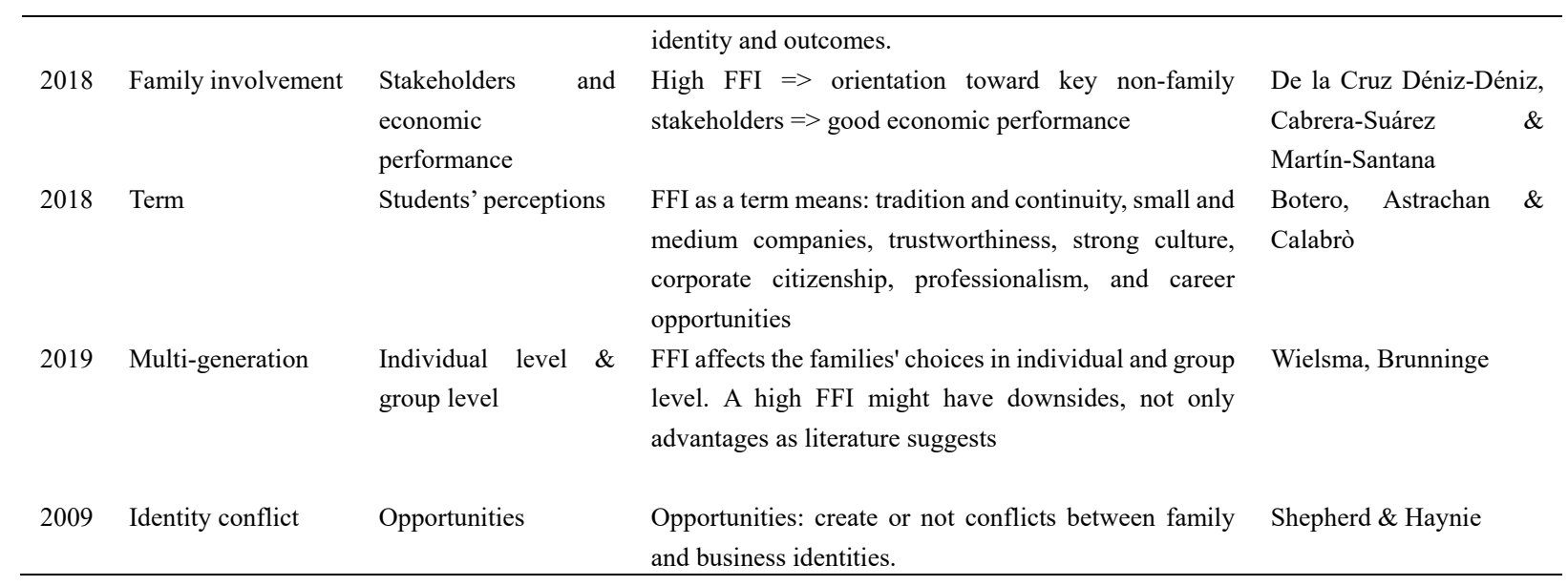

Impressive results are presented in the table above. The time frame of the literature elaborated from this paper belongs to 2008 - 2019. During the last decade, researchers have dedicated many articles to FFI. The table shows the dimensions studied, context, results and information about the source. Dimensions represent the main focus of each study. Authors have treated dimensions in different contexts as well. This is why the background or context is included in this general representation. Context is a factor that gives more detailed information about how the authors have treated or studied each issue. Results are also present in the table, showing the primary outcomes of each paper. Synthesized results reveal essential factors and relationships about FFI.

\section{Conclusions}

The identity that employees share with the family business can influence and also be influenced by many factors. Through this systematic literature review are identified critical dimensions that affect FFI. Different fields are elaborated by scholars, from nonfinancial ones such as conflict, reputation, communication, generation and boundaries to other detailed economic and financial issues. All these elements together help us in creating a broad picture of the concept of FFI.

The literature taken into consideration by this paper suggests that FFI is a critical element that can somehow enhance the performance of the company. The dedication of employees is higher, and also stakeholders attach positive aspects to companies that show a certain degree of FFI. Results present even favorable connotations to the FFI term, but not all the family firms can put it in practice. Some of the factors that affect the FFI from being shared or not are: commitment, pride, differentiation and image. Each company is affected differently by those factors due to its history or marketing strategy. It means that firms can control some aspects of the FFI, but other situations like an inheritance, cannot be adequately controlled. For example, it is challenging to change FFI if the business is influenced for decades by the family.

\section{Limitations and Future Suggestions}

This research has used a single researcher to gather the data, and no software is used to search. In this regard, particular articles might be excluded unintentionally. As a result, the first suggestion for scholars is to use professional software and also rely on more than a person to analyze each paper's content, aiming to create a new perspective. The second one, researchers might examine further the factors that have affected the results revealed in these articles. Last suggestion for future research, is to develop a general framework of the FFI as a process. The frame might include critical phases and factors that affect them.

\section{References}

Astrachan, C. B., \& Botero, I. C. (2018). "We are a family firm": An exploration of the motives for communicating the family business brand. Journal of Family Business Management, 8(1), 2-21. https://doi.org/10.1108/JFBM-01-2017-0002

Astrachan, C. B., Botero, I., Astrachan, J. H., \& Prügl, R. (2018). Branding the family firm: A review, integrative framework proposal, and research agenda. Journal of Family Business Strategy, 9(1), 3-15.

Beck, S. (2016). Brand management research in family firms. Journal of Family Business Management, 6(3), 225-250. http://dx.doi.org.library.esc.edu/10.1108/JFBM-02-2016-0002

Blombäck, A. (2011). Realizing the value of family business identity as corporate brand element - A research 
model. St. Louis: Federal Reserve Bank of St Louis.

Blombäck, A., \& Ramírez-Pasillas, M. (2010). Exploring logics in corporate brand identity formation - the case of family business. St. Louis: Federal Reserve Bank of St Louis.

Botero, I. C., Astrachan, C. B., \& Calabrò, A. (2018). A receiver's approach to family business brands: Exploring individual associations with the term "family firm". Journal of Family Business Management, 8(2), 94-112. https://doi.org/10.1108/JFBM-03-2017-0010

Botero, I. C., Thomas, J., Graves, C., \& Fediuk, T. A. (2013). Understanding multiple family firm identities: An exploration of the communicated identity in official websites. Journal of Family Business Strategy, 4(1), $12-21$.

Brunninge, O., \& Melander A., (2010), Constructing family firm identity over generations: The case of the Swedish pulp and paper firm MoDo 1872-1990. In proceedings of the History by Generations, Washington, DC.

Calabrò, A. Campopiano, G., \& Basco, R. (2017). Principal-principal conflicts and family firm growth: The moderating role of business family identity. Journal of Family Business Management, 7(3), 291-308. https://doi.org/10.1108/JFBM-02-2017-0005

Calabrò, A., Campopiano, G., \& Basco, R. (2017). Principal-principal conflicts and family firm growth: The moderating role of business family identity. Journal of Family Business Management, 7(3), 291-308.

Craig, J. B., Dibrell, C., \& Davis, P. S. (2008). Leveraging family-based brand identity to enhance firm competitiveness and performance in family businesses. Journal of Small Business Management, 46(3), 351-371. https://doi.org/10.1111/j.1540-627X.2008.00248.x

De la Cruz Déniz Déniz, M., Cabrera Suárez, M., K., \& Martín-Santana, J., D. (2018). Orientation toward key non-family stakeholders and economic performance in family firms: The role of family identification with the firm. Journal of Business Ethics, 1-17. https://doi.org/10.1007/s10551-018-4038-4

El Masri, T., Tekathen, M., Magnan, M., \& Boulianne, E. (2017). Calibrating management control technologies and the dual identity of family firms. Qualitative Research in Accounting \& Management, 14(2), 157-188, https://doi.org/10.1108/QRAM-05-2016-0038

Fotea, S., Pop, N.A., \& Fotea, I. (2017). Developing an Understanding of Romanian Consumers' Perception of Family Firms. Proceedings of the ECMLG2017 13th European Conference on Management, Leadership and Governance: ECMLG 2017, London, UK.

Kansikas, J., \& Nemilentsev, M. (2010). Family Business Corporate Identity in the Era of Globalisation. In proceeding of the EIASM FB.

Mays, N., Pope, C. \& Popay, J. (2005), Systematically reviewing qualitative and quantitative evidence to inform management and policy-making in the health field. Journal of Health Services Research and Policy, 10(1), 6-20.

Memili, E., \& Welsh, D., H., B. (2012). Towards a theory of nonfamily employees' organizational identification and attachment in family firms. Journal of Technology Management in China, 7(3), 255-269. https://doi.org/10.1108/17468771311325167

Mulrow, C. D. (1994). Systematic Reviews-Rationale for Systematic Reviews. British Medical Journal, 309(6954), 597-599.

Nunnemacher, H. (2016). Attitudes toward trust, identity, and succession planning over generations in family business (Doctoral dissertation). Available from ProQuest LLC (NR 10103911).

Pagliarussi, M. S., \& Costa, C. (2017). Identity in Family Firms: A Theoretical Analysis of Incentives and Contracts. Brazilian Administration Review, 14(3), 1-25.

Parada, M. J., \& Dawson, A. (2017). Building family business identity through transgenerational narratives. Journal of Organizational Change Management, 30(3), 344-356. http://dx.doi.org.library.esc.edu/10.1108/JOCM-10-2016-0200

Parada, M. J., \& Dawson, A. (2017). Building family business identity through transgenerational narratives. Journal of Organizational Change Management, 30(3), 344-356. https://doi.org/10.1108/JOCM-10-2016-0200

Shepherd, D.A. \& Haynie, J.M. (2009). Family business, identity conflict, and an expedited entrepreneurial 
process: A process of resolving identity conflict. Entrepreneurship Theory and Practice, 33, 1245-1264.

Sundaramurthy, C., \& Kreiner, G. E. (2008). Governing by managing identity boundaries: The case of family businesses: ET\&P ET\&P. Entrepreneurship Theory and Practice, 32(3), 415-436. http://dx.doi.org.library.esc.edu/10.1111/j.1540-6520.2008.00234.x

Szymanska, I. I. (2015). A case study of entrepreneurial orientation and organizational identity negotiation in large, transgenerational family business (Doctoral dissertation). Available from ProQuest LLC (NR 3721075).

Szymanska, I., I., (2015), A Case Study of Entrepreneurial Orientation and Organizational Identity Negotiation in Large. Transgenerational Family Business (Doctoral dissertation).

Thiele, F. K., \& Wendt, M. (2017). Family firm identity and capital structure decisions. Journal of Family Business Management, 7(2), 221-239. https://doi.org/10.1108/JFBM-05-2017-0012

Tranfield, D. R., Denyer, D., \& Smart, P. (2003). Towards a methodology for developing evidence informed management knowledge by means of systematic review. British Journal of Management, 14(3), 207-222.

Whetten, D., Foreman, P., \& Dyer W.G. (2014). Organizational identity and the family business. In: Melin L, Nordqvist M. (Eds.), The SAGE handbook of family business. London: Sage.

Wielsma, A. J., \& Brunninge, O. (2019). "Who am I? Who are we?" Understanding the impact of family business identity on the development of individual and family identity in business families. Journal of Family Business Strategy, 10(1).

Zellweger, T. M., Eddleston, K. A., Franz W., \& Kellermanns, F. W. (2010). Exploring the concept of familiness: Introducing family firm identity. Journal of Family Business Strategy, 1(1), 54-63. https://doi.org/10.1016/j.jfbs.2009.12.003

Zellweger, T. M., Nason, R. S., Nordqvist, M., \& Brush, C. G. (2013). Why do family firms strive for nonfinancial goals? an organizational identity perspective: ET\&P ET\&P. Entrepreneurship Theory and Practice, 37(2), 229-248. http://dx.doi.org.library.esc.edu/10.1111/j.1540-6520.2011.00466.x

\section{Copyrights}

Copyright for this article is retained by the author(s), with first publication rights granted to the journal.

This is an open-access article distributed under the terms and conditions of the Creative Commons Attribution license (http://creativecommons.org/licenses/by/4.0/). 